\title{
HIGHER EDUCATION LECTURERS' SUPPORT/ASSISTANCE IN STUDENT LEARNING: STUDY CASE OF LITHUANIAN HIGHER SCHOOLS
}

\author{
Birutė Jatkauskienė
}

Modestas Nugaras

Klaipeda University, Lithuania

\begin{abstract}
This article analyses a number of aspects of lecturers' support/assistance in student learning. Empirical study reveals support/assistance, provided by lecturers, that is focused on: development of interpersonal relationships, informing, facilitation of learning/studies, regulation of relations, modelling of learning/study activities and behaviour, a vision of student learning, student activities. The above listed aspects of support/assistance might serve as a particular performance indicator for some of lecturers in this field, so as to provide a real and effective help and assure a quality of learning and studies.
\end{abstract}

Keywords: higher school, lecturers, support/assistance provided to students.

\section{Introduction}

One of the fundamental areas of university lecturing staff's activities is providing support/assistance for learning students (Jatkauskienè et al., 2013). A lecturer may be describes as a person-source, an expert, a consultant, or a social intermediary between a learning student and new knowledge, abilities and skills pursued by him/her (Reffay \& Chanier, 2005). By focusing his/her activity on a learner, provision of support and assistance, and dynamics of interaction between a lecturer and a student when acquiring and constructing knowledge, a lecturer, thus, plays a significant role in the process of studies.

Lecturing functions are derived from the theory of constructivist learning, which imposes a learner to engage in the actual process of problem-solving. While learning, a student is not provided a solution to his/her problems, but rather looks for it using individual learning strategies. Therefore, a student must independently plan goals, objectives for learning (studies), and ways to achieve them, set priorities, build up all his/her capability and available resources, and progress to action in cooperation with other learners (Raynal et al., 2007). However, students do not always succeed in this and are faced with a number of problems (of cognitive, affective, psychomotor nature, etc.) (Jatkauskienè et al., 
2011). Quite often, learners and students are left alone with the problems arisen. In such cases, principles of vocation, knowledge, and goodwill should inspire a lecturer to offer support/assistance to learning students, by focusing on the development of interpersonal relationships, informing, facilitation of learning/studies, counselling on relations, modelling of learning/study activities and behaviour, a vision of student learning and studies.

Today, Lithuania lacks not only deeper academic discussions on lecturers' support/assistance for students, but also scholarly studies in this area. The situation is somewhat different for Western European countries. Individual scholars (Reffay \& Chavier, 2005; Maes, 2007; Basque, Rochelen, \& Winer, 2009 ; et al.) have distinguished several aspects of support/assistance for learners:

- $\quad$ support and assistance of didactic nature with respect to content determines the knowledge and competences pursued by a learner (cognitive or meta-cognitive support);

- $\quad$ support and assistance of didactic nature with respect to methodology provides for possible obstructions for organising individual or group activity of learners and helps to eliminate them;

- $\quad$ support and assistance of technical nature determines and helps to eliminate technical problems encountered by learners;

- $\quad$ support and assistance of administrative nature refers to providing information about the educational process to a learner;

- $\quad$ sychological support concerns problems of socio-affective nature (motivation, conflicts, etc. ) and helps to resolve them.

Some scientists (Gounon, Dubourg, \& Leroux, 2004) suggest conceptualisation and modelling of support and assistance provided to a learner based on three perspectives: perspective of an actor that provides support/assistance (e.g., a teacher, tutor, mentor, coacher, colleague, relative, etc.); perspective of an actor that receives support/assistance (e.g., a learning student); a type of support/assistance: proactive, reactive, and contextual. Proactive help presumes support/assistance provided at a lecturer's initiative; reactive help manifests as a lecturer's response to a request for assistance; contextual help is expressed depending on an actual context or situation (Jatkauskienè, 2013).

Support and assistance should reflect a student's cognitive (conceptual, methodological, administrative and technical), social-affective, motivational, and meta-cognitive needs. Given the above, we may state that support/assistance a certain social interaction, related to the self-learning process and can be analysed in various aspects (Jatkauskienè et al., 2011): as support/assistance of social-affective nature (to support someone who is "failing", having learning 
difficulties); as support/assistance of cognitive nature (helping to deal with socio-cognitive conflicts, to regulate interrelations, etc.); as a subject of learning/studies (construction and modelling a correct behaviour). Social space should be adjusted so that students understand their interaction while being an integral part of learning. However, there has been an insufficient comprehensive study carried out in Lithuania on the subject so far. Thus, there has been a scientific problem presupposed: how and by what means is a lecturer's support/assistance in student learning expressed in various academic aspects?

A goal of the research - to analyse theoretically and to reveal empirically aspects of a lecturer's support/assistance for students. In order to achieve the goal, the following problematic issues of research are raised:

- What is a lecturer's support/assistance in terms of development of interpersonal relationships and how is it expressed?

- What is a lecturer's support/assistance in terms of informing and how is it expressed?

- What is a lecturer's support/assistance in terms of facilitation of learning/studies and how is it expressed?

- What is a lecturer's support/assistance in terms of facilitation of regulation of relations and how is it expressed?

- What is a lecturer's support/assistance in terms of modelling of learning/study activities and behaviour and how is it expressed?

- What is a lecturer's support/assistance in terms of vision of student activities and how is it expressed?

Study design. In this qualitative study, the process of designing, construction, primary data collection and rational choice of analysis methods are described as a study design (Bitinas et al., 2008).

The following study methods have been used during the research: analysis of scientific literature for revealing a theoretical background of the study, a meta-analysis for review of previous studies data in this field and using it for interpretation within this study, and interviews for collection of qualitative data to analyse lecturers' support/assistance for students. A sample is based on homogeneous selection, as participants in the research are lecturing or studying at universities and colleges of Lithuania: Klaipeda University, Vytautas Magnus University, Mykolas Romeris University, SMK University of Applied Social Sciences (Klaipeda). The total sample under study is $(n=42)$. The study has involved students $(\mathrm{n}=22)$ and lecturers $(\mathrm{n}=20)$. A study sample in each group (students and lecturers) is supposed to be sufficient for a qualitative analysis, in view of the phenomenological study approach chosen. It has been pursued to attain an internal study validity through the triangulation (interviews with lecturers $(n=20)$, interviews with students $(n=22)$, a group discussion with 
representatives of administration ( $\mathrm{n}=7$ ), and a lecturer's performance monitoring $(\mathrm{n}=5)$. The informants were selected by random sampling, that is, randomly chosen from different Lithuanian higher schools. Teaching service of lecturers who participated in research -11 to 20 years. Among the lecturers under study 11 males and 9 females. The study involved undergraduate students, of which 8 males and 14 females.

Individual interviews and group discussions with representatives of administration can be considered as constraints of the research since the informants' responses to questions could be affected by the following factors: the desire to be a lecturer or a student positively recognised by society, too high/too low self-esteem in demonstration of understanding a lecturer's support/assistance activities, the role, etc. The reliability of study results is validated by audit of research, i.e., checking a consistency in research data collection, interpretations, and findings. The research was audited by professors of Klaipeda University $(\mathrm{n}=2)$. This article provides data obtained in interviews with lecturers and students only.

The study data collection tool (questionnaire) was developed on the basis of a set of specific questions which were verified and validated in some countries (Canada, Finland, Sweden) (Jatkauskiene, 2013). Similar studies have been carried out before at the international level (Boutinet, 2013) ${ }^{1}$.

The research tool - the questionnaire - consists of questions intended to analyse informants' opinion of the lecturers' support/assistance in student learning. The questionnaire is divided into separate parts by topic clusters: 1) support/assistance focused on development of relationships; 2) support/assistance focused on informing; 3) support/assistance focused on facilitation of activities; 4) support/assistance focused on regulation of activities; 5) support/assistance focused on modelling of activities; 6) support/assistance focused on the vision of student learning/studies. At the end of the questionnaire, 3 open questions are provided to base upon for holding a group discussion. Clear guidelines for analysis and interpretation of study data is one of the advantages of the research. It has been observed that qualitative studies on the role of activities or individuals, data collection methods, such as interviews or surveys, are sometimes found to be unreliable because of informants' attempt to provide responses as expected by research organisers (Trigwell et al., 2004). In terms of this research, we can reassure that such likelihood was avoided since the data collection and interpretation techniques precluded the possibility of "model" answers.

\footnotetext{
${ }^{1}$ Boutinet, J. P. (collectif). 2013. L'accompagnement et ses paradoxes, Actes du Colloque International de Fontvraud les 22 et 24 mai 2013.
} 
The following figure reflects the phases of study:

\begin{tabular}{|l|}
\hline Study phases \\
\hline 1. Analysis of scientific literature \\
2. Semi-structured interviews with study participants \\
3. Analysis and summarisation of data obtained in interviews \\
4. Group discussion involving administrative representatives \\
participated in the study \\
5. Monitoring the performance of 7 lecturers \\
6. Development of research report and findings
\end{tabular}

Fig. 1 Study phases

When monitoring lecturers' support/assistance, the following behaviour observation units have been identified: development of relationships, informing, facilitation of learning/studies, regulation of relations, performance modelling, and focus on a vision of student learning/studies.

Study site: Klaipėda University, Vytautas Magnus University, Mykolas Romeris University, SMK University of Applied Social Sciences (Klaipéda).

\section{Results of research and discussion}

Participants of the study were asked to read each statement (a total of 55), to rate it at their discretion using a 5-point scale, with the following estimate values: 1 - never, 2 - rarely, 3 - sometimes, 4 - often, 5 - always. All the statements were divided into separate topic clusters. Each cluster of topics is described by the highest sum of points (estimates) of the statements provided. Such an interpretation of survey data, as part of the lecturer support/assistance analysis, reveals each behavioural goal, insights into the behaviour of a lecturer in not only providing support/assistance, but also in pursuing positive and constructive changes of student learning/studies. As mentioned above, all the statements were grouped into different clusters of topics:

\section{Support/assistance, focused on development of interpersonal relationships}

The following correlations of topic clusters with statements were provided for: $1,5,7,12,13,23,42,44,47$ and 53 . The highest possible sum of estimates -50 . 
Birutè Jatkauskienè, Modestas Nugaras. Higher Education Lecturers' Support/Assistance in Student Learning: Study Case of Lithuanian Higher Schools

Table 1 Support/assistance, focused on development of interpersonal relationships

\begin{tabular}{|c|c|c|c|c|c|}
\hline $\begin{array}{c}\text { Survey } \\
\text { participants/estimate } \\
\text { values }\end{array}$ & $\begin{array}{c}\text { Does not } \\
\text { match - 10- } \\
\mathbf{3 5}\end{array}$ & $\begin{array}{c}\text { Hardly } \\
\text { matches - } \\
\mathbf{3 6 - 3 8}\end{array}$ & $\begin{array}{c}\text { Matches - } \\
\mathbf{3 9 - 4 1}\end{array}$ & $\begin{array}{c}\text { Highly } \\
\text { matches - } \\
\mathbf{4 2 - 4 4}\end{array}$ & $\begin{array}{c}\text { Fully } \\
\text { matches - } \\
\mathbf{4 5 - 5 0}\end{array}$ \\
\hline $\begin{array}{c}\text { Lecturers'point of } \\
\text { view }\end{array}$ & & 36.28 & & & \\
\hline $\begin{array}{c}\text { Students'point of } \\
\text { view }\end{array}$ & 21.85 & & & & \\
\hline
\end{tabular}

As we can see in the table above, from the point of view of lecturers involved in the survey, the average of estimates under this cluster is 36.28. A comparison of the average with highest possible sum of estimates (50) shows that it hardly matches the support/assistance that is focused on the development of interpersonal relationships of lecturers and students.

Even lower average estimates are obtained from the analysis of students' point of view. The average of estimates of students involved in the survey under this cluster is 21.85 out of the highest possible sum of estimates (50). This shows that the students' attitude toward the lecturers' support/assistance, focused on development of interpersonal relationships, does not meet their expectations. For purposes of support/assistance, focused on the development of interpersonal relationships, a lecturer bases upon listening and trust to build a learning/study environment that makes a student talking about his/her positive and negative experiences, without fear of the lecturer's criticism or negative evaluation (Gounon et al., 2004). It implies that this area of support/assistance is to be improved.

A lecturer's support/assistance could be described as understanding, approval, active listening, and empathy (Maltcuit et al., 2005). Support, assistance is a certain style of communication, based on humanism, human values; recognition of a human being and help he needs (Jatkauskiené, 2013). In this case, the interrelation and interaction between a lecturer and a learner are emphasised. Priority is given to a human factor rather that to a problem or a complex situation. However, we should admit that support/assistance is of intervention nature. The process of intervention differs depending on a type of support, assistance, tools used, and a problem to deal with. Sometimes, intervention is directed towards a student's behaviour or professional practice, sometimes - to reflection so as to achieve effective solution of the problem. Nevertheless, the intervention process always comprises the same stages: diagnostics, analysis of situation, development of support/assistance scenario, and planning the implementation of this scenario. In any case, a lecturer playing a role of a mentor, a tutor, or a coacher, is carrying out activities taking a 
student's interests into consideration, therefore, a lecturer should give total freedom and responsibility to a student in making any decisions since the process of intervention in support/assistance is aimed solely on improvement of learning activities.

In order to make a lecturer's support/assistance effective and to develop interrelations, lecturers should demonstrate the following behaviour in their activities: to practice active listening (verbal and non-verbal communication shows a sincere interest); to formulate open questions to make a student analyse a current situation; to provide a descriptive feedback developed during the observation; to make sure whether the lecturer perceives a student's emotions in a right way; to answer questions in the way helping students to understand their own emotions and reactions rather than by categorical judgment (Jatkauskiene 2013).

\section{Support/assistance focused on informing:}

Correlations with the statements $3,4,6,9,10,11,19,24,40$ and 52. The highest possible sum of estimates -50 .

Table 2 Support/assistance, focused on informing

\begin{tabular}{|c|c|c|c|c|c|}
\hline $\begin{array}{c}\text { Survey } \\
\text { participants/Estimate } \\
\text { values }\end{array}$ & $\begin{array}{c}\text { Does not } \\
\text { match - 10- } \\
\mathbf{3 3}\end{array}$ & $\begin{array}{c}\text { Hardly } \\
\text { matches - } \\
\mathbf{3 4 - 3 6}\end{array}$ & $\begin{array}{c}\text { Matches - 37- } \\
\mathbf{3 9}\end{array}$ & $\begin{array}{c}\text { Highly } \\
\text { matches - } \\
\mathbf{4 0 - 4 2}\end{array}$ & $\begin{array}{c}\text { Fully } \\
\text { matches - } \\
\mathbf{4 3 - 4 5}\end{array}$ \\
\hline $\begin{array}{c}\text { Lecturers' point of } \\
\text { view }\end{array}$ & & 34.71 & & & \\
\hline Students' point of view & 18.28 & & & & \\
\hline
\end{tabular}

Given the point of view of lecturers involved in the survey, the average of estimates under this cluster is 34.71 . A comparison of the average with highest possible sum of estimates (50) shows that it hardly matches the support/assistance that is focused on student informing.

Even lower average estimates are obtained from the analysis of students' point of view. The average of estimates of students involved in the survey is 18.28 out of the highest possible sum of estimates (50). These figures show that students' attitude toward their awareness of learning/studies and professional development, as well as goal analysis and specific observations on the appropriateness and usefulness of information sources, does not meet their expectations. A lecturer must make sure that his/her advice is appropriate subject to the situation and is justified by sufficient and adequate information about a particular student (Raynal et al., 2007). Should a lecturer ask a student to submit a comprehensive plan of learning/study activities, professional development goals and objectives, he/she must also provide specific comments 
on information sources that are appropriate and useful for the student. It implies the following positive behaviour of a lecturer (Pineau, 2001): formulation of questions enabling to understand a student's learning/study situation; analysis of a student's prior experiences and planning appropriate learning/studies activities on this basis; formulation of right questions that require definite answers; giving direct comments on a student's current problems and proposals of various solutions to them; reformulation of the information provided to the student so as to attain accuracy of facts and clarity of reasoning; decision-making based on facts.

\section{Support/assistance, focused on facilitation of learning/studies:}

Correlations with the statements $15,22,25,34,39$, and 49 . The highest possible sum of estimates -30 .

Table 3 Support/assistance, focused on facilitation of learning/studies

\begin{tabular}{|c|l|c|c|c|c|}
\hline $\begin{array}{c}\text { Survey } \\
\text { participants/Estimate } \\
\text { values }\end{array}$ & $\begin{array}{c}\text { Does not } \\
\text { match - 6-18 }\end{array}$ & $\begin{array}{c}\text { Hardly } \\
\text { matches - } \\
\mathbf{1 9 - 2 0}\end{array}$ & $\begin{array}{c}\text { Matches - } \\
\mathbf{2 1 - 2 2}\end{array}$ & $\begin{array}{c}\text { Highly } \\
\text { matches - } \\
\mathbf{2 3 - 2 4}\end{array}$ & $\begin{array}{c}\text { Fully } \\
\text { matches } \\
\mathbf{- 2 5 - 3 0}\end{array}$ \\
\hline $\begin{array}{c}\text { Lecturers' point of } \\
\text { view }\end{array}$ & & & & 23.00 & \\
\hline $\begin{array}{c}\text { Students' point of } \\
\text { view }\end{array}$ & 10.71 & & & & \\
\hline
\end{tabular}

Given the point of view of lecturers involved in the survey, the average of estimates under this cluster is 23 . A comparison of the average with highest possible sum of estimates (30) shows that it highly matches the support/assistance provided, that is focused on facilitation of learning/studies.

The average, however, is significantly lower in view of the students' attitude. Given the point of view of students involved in the survey, the average of estimates under this cluster is 10.71 out of the highest possible sum of estimates (30). Students, thus, believe that lecturers do not help them to analyse their interests, capabilities, skills, ideas, attitudes, beliefs, values, related to the learning/studies and professional environment. A lecturer should encourage a student to assess an actual performance, by adopting appropriate decisions in learning/studies, and help the student to analyse his/her interests, capabilities, skills, ideas, attitudes, beliefs, values in relation to the learning/studies and professional environment (Zuzevičiūtè et al., 2011). A teacher should demonstrate a positive behaviour in the area of facilitation of learning/studies as follows: formulation of questions and structuring hypotheses, so as to expand a student's vision in learning/study activities, hypotheses that would be based on the lecturer's experience and unbiased information; help in improving 
understanding of various and numerous approaches so that to gain a more detailed insight into the decision-making analysis; assessment of a student's commitment to pursue his/her goals; analysis of reasons that help to describe a student's responsibilities and objectives; analysis of a student's learning/study activities, vocational interests, etc. (Jatkauskienè, 2013).

\section{Support/assistance, focused on regulation of relations:}

Correlations with the statements $8,16,18,21,27,31,33,37,43,46,48$, and 51 . The highest possible sum of estimates -60 .

Table 4 Support/assistance, focused on regulation of relations

\begin{tabular}{|c|l|l|l|l|l|}
\hline $\begin{array}{c}\text { Survey } \\
\text { participants/Estimate } \\
\text { values }\end{array}$ & $\begin{array}{c}\text { Does not } \\
\text { match - } \\
\mathbf{1 2 - 3 9}\end{array}$ & $\begin{array}{c}\text { Hardly } \\
\text { matches - } \\
\mathbf{4 0 - 4 3}\end{array}$ & $\begin{array}{c}\text { Matches - } \\
\mathbf{4 4 - 4 6}\end{array}$ & $\begin{array}{c}\text { Highly } \\
\text { matches - } \\
\mathbf{4 7 - 5 0}\end{array}$ & $\begin{array}{c}\text { Fully } \\
\text { matches } \\
\mathbf{- 5 1 - 6 0}\end{array}$ \\
\hline Lecturers' point of view & & & 44.57 & & \\
\hline Students' point of view & 22.00 & & & & \\
\hline
\end{tabular}

Given the point of view of lecturers involved in the survey, the average of estimates under this cluster is 44.57. A comparison of the average with highest possible sum of estimates (60) shows that it matches the support/assistance provided is focused on regulation of relations. Analysis of the average of students' estimates shows lower results. Given the point of view of students involved in the survey, the average of estimates under this cluster is 22 out of the highest possible sum of estimates (60). This shows that, from the students' point of view, lecturers' support/assistance, focused on regulation of relations, does not meet their expectations. A lecturer should help a student to realise his/her unproductive and ineffective performance strategy and behaviour, on this basis, to suggest positive methods, ways to change learning/study capabilities. A lecturer has to show respect when criticising a student's interpretation or apologies in relation to the latter's refusal to take an appropriate action or decision in terms of learning/studies improvement. Therefore, a lecturer's support/assistance, focused on the regulation of relations, should be demonstrated as follows (Quintin, 2007): appreciation of a student's willingness to accept different points of view; openly expressing his/her concerns about the potential impact of constructive criticism on support/assistance relationships; regulation of relations, which will help and enable a student to question conflicts in learning/study objectives, commitment and performance in pursuance of learning/study objectives; choosing the most effective performance strategy and behaviour to induce a student for major changes; where appropriate, providing 
direct and critical feedback so as to improve a student's understanding; where a student questions the appropriateness of activities, formulating comments, thereby, suggesting opportunities for his/her learning/study growth.

5. Support/assistance, focused on modelling of learning/study activities:

Correlations with the statements $2,28,29,32,26$, and 41 . The highest possible sum of estimates -30 .

Table 5 Support/assistance, focused on modelling of learning/study activities

\begin{tabular}{|c|c|c|c|c|c|}
\hline $\begin{array}{c}\text { Survey } \\
\text { participants/Estimate } \\
\text { values }\end{array}$ & $\begin{array}{c}\text { Does not } \\
\text { match }- \\
\mathbf{6 - 1 8}\end{array}$ & $\begin{array}{c}\text { Hardly } \\
\text { matches - } \\
\mathbf{1 9 - 2 0}\end{array}$ & $\begin{array}{c}\text { Matches - } \\
\mathbf{2 1 - 2 2}\end{array}$ & $\begin{array}{c}\text { Highly } \\
\text { matches - } \\
\mathbf{2 3 - 2 4}\end{array}$ & $\begin{array}{c}\text { Fully } \\
\text { matches - } \\
\mathbf{2 5 - 3 0}\end{array}$ \\
\hline $\begin{array}{c}\text { Lecturers'point of } \\
\text { view }\end{array}$ & & & & 23.00 & \\
\hline $\begin{array}{c}\text { Students'point of } \\
\text { view }\end{array}$ & 10.71 & & & & \\
\hline
\end{tabular}

As we can see in the table above, the average of estimates of lecturers involved in this study under this cluster is 23 . A comparison of the average with highest possible sum of estimates (30) shows that this estimate matches the support /assistance provided that is focused on modelling of learning/study activities.

Again, analysis of students' responses shows a lower average of estimates. The average of estimates of students involved in this study under this cluster is 12 out of the highest possible sum of estimates (30). This shows that, from the students' point of view, lecturers' support/assistance, focused on modelling of learning/study activities, does not meet their expectations. A lecturer should motivate students to take right decisions, a risk, thereby, to confront difficulties in implementation of learning/study or career objectives. Lecturers might openly share their experiences or emotions, become a "model" for a student, thus, enriching mutual relationships (Raynal et al., 2007).

In this case, a lecturer's positive behaviour might be defined as follows: a lecturer expresses his/her own opinion, feelings, emotions, negative experiences so as to stimulate student learning, positive aspects of learning/studies, a potential positive impact of it on careers, personal development; where appropriate, a lecturer gives examples of his/her own experiences and life; shows confidence in a student's ability to make the right decisions in pursuance of learning/study goals (Raynal et al., 2007).

6. Support/assistance, focused on vision of a student's learning/studies:

Correlations with the statements $14,17,20,26,30,35,38,45,50,54$, and 55 . The highest possible sum of estimates -55 . 
Table 6 Support/assistance, focused on the vision of learning/studies

\begin{tabular}{|c|c|c|c|c|c|}
\hline $\begin{array}{c}\text { Survey } \\
\text { participants/Estimate } \\
\text { values }\end{array}$ & $\begin{array}{c}\text { Does not } \\
\text { match }-11- \\
\mathbf{3 7}\end{array}$ & $\begin{array}{c}\text { Hardly } \\
\text { matches - } \\
\mathbf{3 8 - 4 1}\end{array}$ & $\begin{array}{c}\text { Matches } \\
\mathbf{4 2 - 4 4}\end{array}$ & $\begin{array}{c}\text { Highly } \\
\text { matches - } \\
\mathbf{4 5 - 4 7}\end{array}$ & $\begin{array}{c}\text { Fully } \\
\text { matches } \\
\mathbf{- 4 8 - 5 5}\end{array}$ \\
\hline $\begin{array}{c}\text { Lecturers' point of } \\
\text { view }\end{array}$ & & 38.14 & & & \\
\hline $\begin{array}{c}\text { Students' point of } \\
\text { view }\end{array}$ & 18.14 & & & & \\
\hline
\end{tabular}

Given the point of view of lecturers involved in the survey, the average of estimates under this cluster is 38.14. A comparison of the average with highest possible sum of estimates (55) shows that it hardly matches the support/assistance which is focused on vision of a student's learning/studies. Even lower average estimates are obtained from the analysis of students' point of view. The average of estimates of students involved in this study under this cluster is 18.14 out of the highest possible sum of estimates (55). Students, thus, believe that lecturers' support/assistance, focused on the vision of a student's learning/studies, does not meet their needs. A lecturer should encourage a student to take his/her own initiative in overcoming difficult stages of learning/studies, in shifting to the academic environment, induce a student's critical thinking about future professional careers, and assist him/her in studying various approaches of personal and professional potential development.

A lecturer's positive behaviour should be manifested as follows (Reffay et al., 2005): commenting that makes a student think of future careers, learning/studies; raising questions for establishing control over a student's negative and positive competencies and changes by reviewing a range of personal available sources, opportunities; commenting on a student's decisionmaking, problem-solving strategy; showing confidence in decisions thoroughly considered and made by a student; observing a student's competencies to help $\mathrm{him} / \mathrm{her}$ foresee his/her professional future; encouraging a student to develop existing skills, abilities, talents, to pursue his/her dreams.

\section{Findings}

1. Having conducted an analysis of theoretical insights and basing on results of the empirical research, we can assert that support and assistance provided to learners is not a one-time tool but rather a creative area of activity that helps to change and develop new attitudes and behaviour, invites to review mental maps, perception, cognition, conception, and vision of the world. 
2. The study has found that the attitude of lecturers and students toward the support/assistance provided at a university or other institution of higher education often does not match.

3. The study has revealed that a lecturer's support/assistance focused on development of interpersonal relationships, according to lecturers and students, is to be improved, since the average of lecturers' estimates is 36.28 , students -21.85 out of 50 (the highest possible sum of estimates).

4. A lecturer's support/assistance focused on informing is inadequate, as analysis of the research data shows that the average of lecturers' estimates is 34.71 , students' -18.28 out of 50 (the highest possible sum of estimates).

5. A lecturer's support/assistance, focused on facilitation of learning/studies, is basically in line with the requirements for lecturers in providing support/assistance, however, students' estimates - 10.71 out of 30 (the highest possible sum of estimates) - radically contrast the results of the research.

6. A lecturer's support/assistance focused on the regulation of relations just partially meets the criteria as the average of lecturers' estimates is 44.57 out of 60 (the highest possible sum of estimates). However, getting deeper into students' estimates (22.00), we may see the very different attitude whereby the students' expectations are not met by lecturers' support/assistance activities.

7. A lecturer's support/assistance focused on the modelling of learning/study activities and behaviour highly meets the set criteria as the average of lecturers' estimates is 23.00. However the one of students' estimates 10.71 out of 30 (the highest possible sum of estimates) - shows that support/assistance focused on the modelling of learning/study activities and behaviour does not meet students' needs.

8. A lecturer's support/assistance focused on the vision of a student's activities should be improved as well, for the reason that the average of lecturers' estimates is 38.14 , students' - 18.14 out of 55 (the highest possible sum of estimates). The significant difference in lecturers' and students' opinions shows that the field provided for support/assistance is not completely filled by lecturers' appropriate behaviour.

\section{References}

Basque, J., Rochelen, J., \& Winer, L. Une approche pédagogique pour l'école informatisée [A pedagogical approach for the computerised school]. Retrieved from http://www.grics.ge.ca/cles_en_main/

Bitinas, B., Rupšienè, L., \& Žydžiūnaitè, V. (2008). Kokybiniu tyrimu metodologija [Methodology of Qualitative Research]. Klaipeda, Lithuania: SJ Publishing Printing. 
Gounon, P., Dubourg, X., \& Leroux, P. (2004). Un modèle d'organisation du tutoral pour la conception de dispositifs informatiques d' accompagnement des apprenants [A model of organizing a tutorial for the conception of computer devices of accompanying learners]. In Technologies de l'Information et de la Connaissance dans l'Enseignement Supérieur et de l'Industrie [Workshop on information and knowledge technologies in higher education and industry] (pp. 369-376). Compiègne, France: Université de Technologie de Compiègne.

Jatkauskienè, B., \& Jovarauskaitè, A. (2011). Tutoriaus veikla paramos/pagalbos aspektu [Tutorship activities in the context of support/assistance]. Klaipėda, Lithuania: Klaipeda University Press.

Jatkauskienè, B., \& Andriekienè, R. M. (2013). Universiteto dèstytoju veiklos daugiafunkcionalumas profesionalizacijos kontekste. Klaipedos universiteto atvejis. Monografija [Multifunctionality of university teachers' activities in the context of professionalization. Study case of Klaipeda University. Monograph]. Klaipeda, Lithuania: Klaipėda University Press. ISBN 978-9955-18-722-6.

Malcuit, G. A., Pomereau, A., \& Maurine, P. (2005). Psychologie de l'apprentissage: termes et concepts [Psychology of learning: terms and concepts]. Maloine, France: Edisem.

Maes, A. (2007). Le nouveu paradigme de la formation à distance: apprentissage active et collaborative [The new paradigm of distance learning: active and collaborative learning]. Montpellier, France: University of Montpellier.

Pineau, G. (2001). Accompagnement et histoire de vie [Accompaniment and life history] (pp. 157-173). Paris, France: L'Harmattan.

Quintin, J. J. (2007). L'impact du tutorat sur les performances des étudiants: Effet de cinq modalités d'intervention tutorale sur les performances d'étudiants engagés dans un travail collectif asynchrone [The Impact of tutoring on student performance: effect of five modes of tutorial intervention on the performance of students engaged in asynchronous collective work]. In Nodenot, T., Wallet J., and Fernandes E., (Eds), Environnements informatiques pour l'apprentissage humain [Computer Environments for Human Learning] (pp. 221-232). Lausanne, Switzerland.

Raynal, F., \& Rieunier, A. (2007). Enseigner du être enseignant. Quel rôle pour la médiation dans la transposition didactique. Théorie et pratique en français, éditions de la Fondation „Ecoul sufletului [Tutor's teaching. What role is for mediation in didactic transposition? Theory and practice in French, editions of the Foundation "Ecoul sufletului"'] (pp. 45-49). Ramnicu Valcea, Romania.

Reffay, Chr., \& Chavie, T. (2005). Approche minimaliste de la formation d'enseignants du supérieur au rôle de concepteur - tuteur de cours en ligne [Minimalist approach to the training of higher education teachers in the role of designer - tutor of online courses]. Paris, France: DUNOD.

Trigwell, K., \& Prosser, M. (2004). Development and use of the approaches to teaching inventory. Educational Psychology Review, 16 (4), 409-424.

Zuzevičiūtè, V., \& Teresevičienè, M. (2011). Universitetinès studijos mokymosi visa gyvenima perspektyvoje. Monografija [University studies in the lifelong learning perspective. Monograph]. Kaunas, Lithuania: Vytautas Magnus University. 